\title{
THE IMPACT OF FINANCING IN ISLAMIC BANKING ON INDONESIAN ECONOMIC GROWTH
}

\author{
Pertiwi Rasyida*, Syathiri Ahmad, Yulianita Anna \\ Department of Economy, Faculty of Economy, University of Sriwijaya, Indonesia \\ *E-mail: pertiwirasyida@gmail.com
}

\begin{abstract}
This research is conducted to investigate the impact of Islamic bank financing in agriculture sector, minning, Industry, electricity, gas and water supply and Construction sector to Indonesia economic growth over the period 2011Q1-2019Q4. This study uses descriptive and quantitative analysis using Eviews 9 to simplify data calculations and estimation and using time series data with Ordinary Least Square Approach. Based on the results of data processing, it is known that Islamic banking financing in the agricultural, minning electricity, gas and water and conctruction sector has a positive effect on economic growth. Meanwhile industrial sector in Islamic banking does not have a significant effect on economic growth. An increase in industrial sector financing by 1 percent is able to reduce GDP by 0.46940 percent. This estimation shows $\mathrm{R}$-Square value is 98 percent influenced by variable financing in the agricultural sector, mining sector, industrial sector, electricity sector, gas and water and the construction sector, while the remaining 2 percent is influenced by other variables outside the model. The agriculture, mining, electricity, gas \& water and construction sectors have a positive influence on economic growth. Meanwhile, the industrial sector has a negative influence on economic growth.
\end{abstract}

\section{KEY WORDS}

Economic growth, Islamic banking, sectoral financing, Ordinary Least Square.

The Islamic finance industry globally has experienced asset growth from year to year. Islamic financial assets grew 3.5 percent year on year or around US \$ 2.52 billion in 2018 with asset distribution dominated by Islamic Banking at 70 percent, Islamic sukuk 19 percent, Islamic Funds 4 percent and other at 7 percent. Indonesia is among the top 10 in the world in terms of Islamic financial assets, that is, $7^{\text {th }}$ with a total asset of $\$ 86$ billion in 2018 (Standard, 2019).

According to Financial Service Authority (2019), The data of Sharia Banking Statistics show that In Indonesia there were 14 Islamic Commercial Banks and 20 Islamic Business Units with a total of 2,229 Islamic banking offices in 2018, an increase from 2,169 offices in 2017 and assets increasing from Rp. 424,181 billion in 2017 to Rp. 477,327 billion 2018 (Authority, 2019).

Islamic banking that comply with Islamic principles has developed over the past few decades and has shown its existence and feasibility to be aligned with the existing conventional banking system. Although Islamic banking functions as a bank that aims to maximize profits, Islamic banking is also limited by laws based on Al Quran and Sunnah. Similar with Conventional Banks, Islamic banks function as intermediaries for channeling and there is a deficit saving sector to encourage activities in the economic sector. The difference is that the financial instrument is interest-free and runs according to Islamic law (Yusof \& Bahlous, 2013).

Islamic finance can play an important role in encouraging economic growth in Indonesia, namely by financing the real sector. The development of the banking sector in which banks have the main function as agents of development and financial intermediary is one way to support the development of a country. The real sector relationship is inseparable from the banking world to develop the real sector, banking support is needed so that the national real sector is able to compete not only in the regional market but also in the in 
ternational market. If the national real sector is developed, it will increase national income for Indonesia's economic development.

\section{LITERATURE REVIEW AND HYPOTHESIS DEVELOPMENT}

Research on the relationship between Islamic banking and economic growth has been widely carried out. Abduh (2012) has found a positive relationship that occurred in Bangladesh between Islamic banking and economic growth. Besides that, Mc. Kinnon and Shaw (1973) in Orji, Ogbuabor, \& Anthony-Orji (2015) state that an organized financial structure can accelerate economic growth.

The relationship between financial sector development and economic growth is first presented in the work of Schumpeter (1911). He emphasized that the services provided by financial institutions can encourage technological innovation and economic growth by financing in productive investment.

This research will focus on financing strategic sectors to support the development of a higher and more competitive economy. So that it is known which sectors have played a major role in boosting Indonesia's economic growth. The sectors to be studied are agriculture, mining, construction, industry, electricity, gas and water in Islamic banking.

Mankiw (2006) describes the theories about the economic growth. Based on the classical economic growth theory pioneered by Adam Smith, economic development is strongly influenced by the stock of capital. The country growth depends on the stock of capital or the amount of available funds for development. The level of output as a result of production also has a close influence on the amount of capital stock.

Meanwhile, Domar (1957) argues that the formation of capital is very necessary as a condition for achieving strong economic growth (Steady growth). If the formation of capital has been carried out, the economy will be able to produce goods and services in greater quantities. Harrod Domar's theory views that there is an economic relationship between the size of the capital stock $(\mathrm{K})$ and the level of output $(\mathrm{Y})$ or better known as the capital-output ratio (Capital output ratio $=$ COR).

Schumpeter (1911) argues that economic growth is largely determined by entrepreneurial abilities (entrepreneurship) because entrepreneurs are able to innovate in production activities. The existence of a stock of new relevant ideas and a source of capital from financial institutions for entrepreneurs to innovate so that a breakthrough can be created is very important in driving economic growth.

The Solow-Swan theory explains how the level of saving and investment, population growth and technological progress affect the level of economic output and growth over time (as cited in Mankiw N., 2006). This classical growth theory can also be presented in the form of the Cobb-Douglas production function where output is a function of labor and capital. Meanwhile, technological progress is an exogenous variable. The Cobb-Douglas function can be written as follows:

$$
Q_{y}=T_{y} K_{y}{ }^{a} L_{y}{ }^{b}
$$

Where: $Q_{y}$ Production rate year y; $T_{y}$ : Technology Level year $y ; K_{y:}$ Total stock of capital goods in year $y$; $L_{y}$ : Number of workers in year y; a: Addition of goods and services due to the addition of one capital unit; $b$ : The addition of goods and services due to the addition of one unit of labor.

Previous researchers have conducted various studies in the field of finance, including those conducted by (Sipahutar, 2016), (Boukhatem \& Ben Moussa, 2018), Suna (2015) showed that between bank credit and economic growth has positive and significant relationship.

In other studies about Islamic banking financing, Terminanto \& Rama (2017); El Ayyubi, Anggraeni, \& Mahiswari (2018); Setiawan (2019); Indrawan \& Rahman (2020) state that Islamic financing has positif and significant impact on economic growth. Meanwhile, Gaffar \& Osman (2014); Baehaqy \& Cahyono (2020) shows that Islamic banking financing 
has a negative and significant relationship to GDP. Afandi \& Amin (2019) state that working capital financing, investment financing and consumer financing have no significant effect on economic growth. Working capital financing and consumer financing have a positive effect on economic growth. Meanwhile, investment financing has a negative effect on economic growth.

Research about sectoral banking financing shows by Oni, Akinlo, \& Oladepo (2014), they found that bank credit has a significant effect on the growth of industrial products in both the short and long term. Meanwhile, the agricultural sector does not have a significant relationship both in the short and long term. Ananzeh (2016) state that if industrial credit increases 1 percent, Jordan's GRDP increases 0.0812 percent in the short run. When agricultural credit increases by 0.01 , GDP increases by 0.0193 percent.

Based on the description above and based on the Cobb-Douglas production function added by the Solow framework (1956), the conceptual framework of this study is as follows:

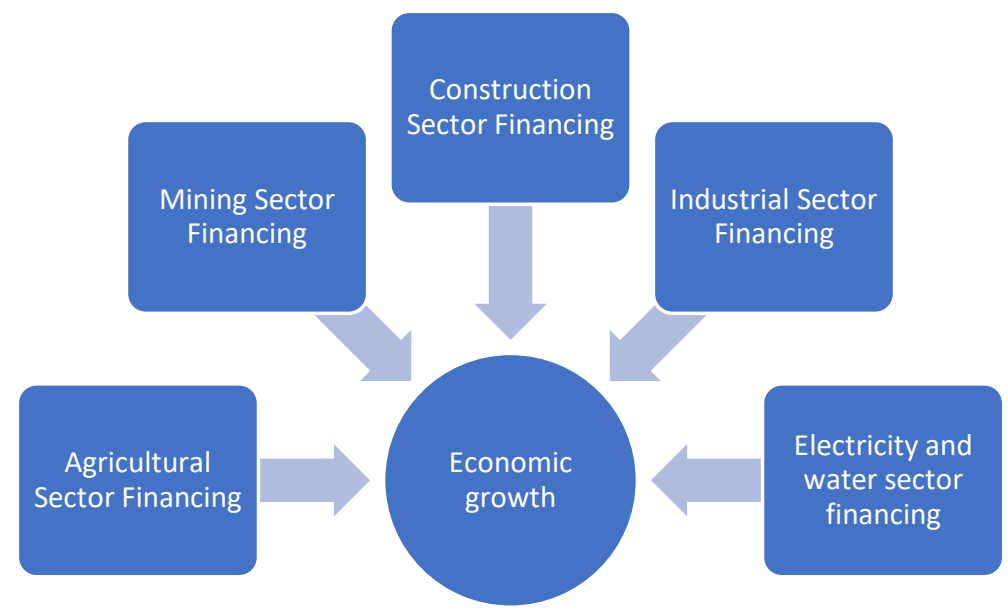

Figure 1 - The Conceptual Framework (Source: built by the authors according to the theory)

The purpose of this research is to investigate how much influence the financing of the agricultural, mining, industrial, electricity, gas and water sectors and construction of Islamic banking on Indonesia's economic growth in 2011 to 2019.

\section{METHODS OF RESEARCH}

This Study uses a quantitative approach. The type of data used in this study is secondary data in the form of quarterly time series data from 2011 to 2019 . This study uses GDP Sectoral data in trillion at constant prices in 2010 and Islamic banking financing data which use financing in the agriculture, mining, industry, electricity, gas \& water and construction sectors in trillion.

Table 1 - Descriptive Statistics of Variables Used in This Study

\begin{tabular}{|c|c|c|c|c|c|c|}
\hline & LNGDP & LNFAGR & LNFMN & LNFIND & LNFEGW & LNFCONC \\
\hline Mean & 3.348000 & 0.760571 & 0.584571 & 1.026000 & 0.751714 & 1.049714 \\
\hline Median & 3.350000 & 0.860000 & 0.700000 & 1.170000 & 0.760000 & 1.050000 \\
\hline Maximum & 3.440000 & 1.170000 & 0.850000 & 1.430000 & 1.210000 & 1.480000 \\
\hline Minimum & 3.240000 & 0.290000 & 0.030000 & 0.380000 & 0.190000 & 0.660000 \\
\hline Std. Dev. & 0.057179 & 0.308306 & 0.246497 & 0.338841 & 0.278583 & 0.238482 \\
\hline Skewness & -0.045935 & -0.288110 & -0.744620 & -0.537706 & -0.054804 & 0.181737 \\
\hline Kurtosis & 1.871266 & 1.504693 & 2.219180 & 1.757533 & 2.226260 & 1.909704 \\
\hline Jarque-Bera & 1.870284 & 3.744961 & 4.123462 & 3.937842 & 0.890587 & 1.926253 \\
\hline Probability & 0.392530 & 0.153742 & 0.127234 & 0.139607 & 0.640636 & 0.381698 \\
\hline Sum & 117.1800 & 26.62000 & 20.46000 & 35.91000 & 26.31000 & 36.74000 \\
\hline Sum Sq. Dev. & 0.111160 & 3.231789 & 2.065869 & 3.903640 & 2.638697 & 1.933697 \\
\hline Observations & 35 & 35 & 35 & 35 & 35 & 35 \\
\hline
\end{tabular}

Source: Eviews. 
Islamic banking financing in the agricultural, industrial, mining, construction and electricity and water sectors is taken from the Indonesian Banking Statistics (SPI) which published by the Financial Services Authority (OJK) and GDP is obtained through the GDP realization report published by the Central Statistics Agency (BPS).

From the table 1 shows that each variable consists of 35 data with the following explanation:

1. The GDP variable grows with a minimum growth value of 3.24 percent and a maximum GDP growth of 3.44 percent, a standard deviation of 0.05 percent, and the average GDP growth from 2011 to 2019 is 3.34 percent;

2. The agricultural variable grows with a minimum growth is 0.29 percent and a maximum growth is 1.17 percent. Meanwhile, the standard deviation is 0.30 percent and the average growth in financing in the agricultural sector from 2011 to 2019 grew by 0.76 percent;

3. Minimum growth of mining sector financing is 0.03 percent and a maximum growth is 0.85 percent. Meanwhile, the standard deviation is 0.24 percent and the average growth rate in this sector from 2011 to 2019 is 0.58 percent;

4. Minimum growth in industrial sector financing is 0.38 percent and a maximum growth of 1.43 percent. The standard deviation is at 0.24 percent with an average growth from 2011 to 2019 of 1.02 percent;

5. Variable financing in the electricity, gas and water sector has a minimum growth of 0.19 percent and a maximum growth is 1.21 percent. The standard deviation is 0.27 percent and the average growth in financing in the electricity, gas and water sector has grown by 0.75 percent for the period 2011 to 2019 ;

6. The financing variable in the construction sector has a minimum growth of 0.66 percent and a maximum growth of 1.48 percent. The standard deviation of financing in the construction sector is 0.23 percent with an average growth rate of 1.04 percent in this sector.

The model used in this study is based on the Cobb-Douglas production function augmented by Solow's (1956) framework. By adopting the theory and equation model above, the results of the equation model specifications used in this study are:

$$
G D P=\beta 0+\beta 1 F A g r+\beta 2 F M n+\beta 3 F I n d++F E g w+\beta 4 F C o n+e i
$$

Where: GDP: Economic growth (GDP); FAgr: Agricultural Sector Islamic Bank Financing; FMn: Mining Sector Islamic Banking Financing; FInd: Industrial Sector Islamic Banking Financing; Fegw: Electricity, Gas and Water Sector Islamic Banking Financing; FConc: Construction sector Islamic Banking Financing.

This study uses descriptive and quantitative analysis using Eviews 9 to simplify data calculations and estimation. The analysis was carried out using Islamic bank sectoral financing variables which are thought to affect Indonesia's economic growth partially or completely by using the Ordinary Least Square (OLS) method.

\section{RESULTS AND DISCUSSION}

Based on the results of the Unit Root Test with the Phillips Pheron method at the level, it shows that the PP Fisher Chi Square Probability value is $0.000<\alpha=0.05$, which means that all variables are stationary at the level.

Table 2 - Unit Root Test using Phillips-Perron at the level

\begin{tabular}{lll}
\hline Method & Statistic & Prob. $^{{ }^{*}}$ \\
\hline ADF - Fisher Chi-square & 101.324 & 0.0000 \\
ADF - Choi Z-stat & -8.19103 & 0.0000 \\
\hline
\end{tabular}

Source: Eviews. 


\section{Eurasia: Economics \& Business, 2(44), February 2021}

DOI https://doi.org/10.18551/econeurasia.2021-02

Based on the regression results using the Johansen cointegration test method, it is known that the trace statistic value of 169.99 is greater than the critical value of 117.708 , which means that all variables are co-integrated in the long run.

Table 3 - Cointegrity Test using Johansen Cointegration

\begin{tabular}{|c|c|c|c|c|}
\hline \multicolumn{5}{|c|}{ Unrestricted Cointegration Rank Test (Trace) } \\
\hline $\begin{array}{l}\text { Hypothesized } \\
\text { No. of CE(s) }\end{array}$ & Eigenvalue & $\begin{array}{l}\text { Trace } \\
\text { Statistic }\end{array}$ & $\begin{array}{l}0.05 \\
\text { Critical Value }\end{array}$ & Prob.** \\
\hline None * & 0.882971 & 169.9953 & 117.7082 & 0.0000 \\
\hline At most 1 * & 0.766597 & 99.19913 & 88.80380 & 0.0072 \\
\hline At most 2 & 0.432070 & 51.18444 & 63.87610 & 0.3627 \\
\hline At most 3 & 0.394344 & 32.51445 & 42.91525 & 0.3611 \\
\hline At most 4 & 0.246046 & 15.96684 & 25.87211 & 0.4952 \\
\hline At most 5 & 0.182430 & 6.646839 & 12.51798 & 0.3828 \\
\hline
\end{tabular}

Source: Eviews.

Residual Normality Test, based on the results of the normality test, the probability value of $\mathrm{JB}$ is $0.489>\alpha=0.05$, which means that the equation model is normally distributed.

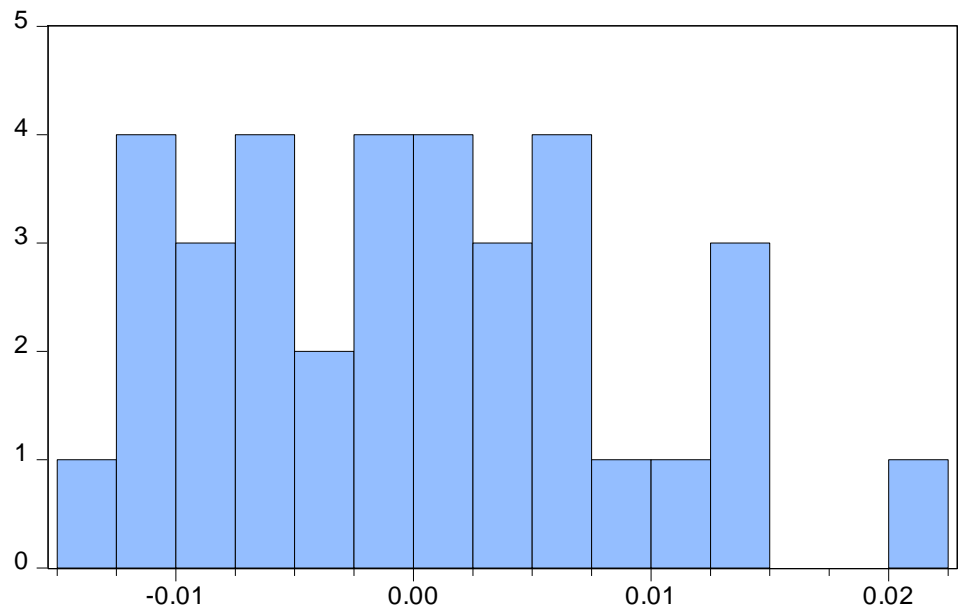

\begin{tabular}{|lr}
\hline \multicolumn{2}{l}{ Series: Residuals } \\
Sample 2011Q1 2019Q3 \\
Observations 35 \\
Mean & $-7.55 \mathrm{e}-16$ \\
Median & -0.000579 \\
Maximum & 0.020531 \\
Minimum & -0.014100 \\
Std. Dev. & 0.008606 \\
Skewness & 0.414021 \\
Kurtosis & 2.451474 \\
& \\
Jarque-Bera & 1.438697 \\
Probability & 0.487069 \\
\hline
\end{tabular}

Figure 2 - Normality Test using Jarque Bera (Source: Eviews)

Heteroscedasticity problem-free model, because the value of Prob. Chi-Square $=0.844$ $>0.05$, meaning that Ho is accepted, or homoscedasticity.

Table 4 - Heteroskedasticity Test using Breusch-Pagan-Godfrey

\begin{tabular}{|l|l|l|l|}
\hline Heteroskedasticity Test: Breusch-Pagan-Godfrey \\
\hline Null hypothesis: Homoskedasticity & 0.357699 & Prob. F(5,29) & 0.8730 \\
\hline F-statistic & 2.033140 & Prob. Chi-Square(5) & 0.8445 \\
\hline Obs ${ }^{\text {R-squared }}$ & 1.012993 & Prob. Chi-Square(5) & 0.9615 \\
\hline Scaled explained SS &
\end{tabular}

Source: Eviews.

The model no longer experiences autocorrelation problems, because the value of DW $=1.827$ is in the range of Rule of Thumb values and there is no autocorrelation. Evidenced by the LM test, where the probability of the LM test is $0.5802>0.05$, which means that $\mathrm{Ho}$ is accepted and is free of autocorrelation. 
Eurasia: Economics \& Business, 2(44), February 2021

DOI https://doi.org/10.18551/econeurasia.2021-02

Table 5 - Autocorrelation Test using LM Test

Breusch-Godfrey Serial Correlation LM Test:

Null hypothesis: No serial correlation at up to $1 \mathrm{lag}$

\begin{tabular}{llll}
\hline \hline F-statistic & 0.246847 & Prob. F(1,28) & 0.6232 \\
Obs ${ }^{\star}$ R-squared & 0.305862 & Prob. Chi-Square(1) & 0.5802 \\
\hline
\end{tabular}

Test Equation:

Dependent Variable: RESID

Method: Least Squares

Date: 11/02/20 Time: 20:37

Sample: 2011Q1 2019Q3

Included observations: 35

Presample missing value lagged residuals set to zero.

\begin{tabular}{|c|c|c|c|c|}
\hline Variable & Coefficient & Std. Error & t-Statistic & Prob. \\
\hline C & 0.000913 & 0.015532 & 0.058789 & 0.9535 \\
\hline LNFAGR & 0.000866 & 0.038553 & 0.022456 & 0.9822 \\
\hline LNFMN & -0.003165 & 0.032781 & -0.096556 & 0.9238 \\
\hline LNFIND & 0.002765 & 0.045007 & 0.061428 & 0.9515 \\
\hline LNFEGW & 0.001024 & 0.025681 & 0.039860 & 0.9685 \\
\hline LNFCONC & -0.003154 & 0.030797 & -0.102398 & 0.9192 \\
\hline $\operatorname{RESID}(-1)$ & 0.097128 & 0.195492 & 0.496837 & 0.6232 \\
\hline R-squared & 0.008739 & \multicolumn{2}{|c|}{ Mean dependent var } & $-7.55 E-16$ \\
\hline Adjusted R-squared & -0.203674 & \multicolumn{2}{|c|}{ S.D. dependent var } & 0.008606 \\
\hline S.E. of regression & 0.009442 & \multicolumn{2}{|c|}{ Akaike info criterion } & -6.310444 \\
\hline Sum squared resid & 0.002496 & \multicolumn{2}{|c|}{ Schwarz criterion } & -5.999374 \\
\hline Log likelihood & 117.4328 & \multicolumn{2}{|c|}{ Hannan-Quinn criter. } & -6.203063 \\
\hline F-statistic & 0.041141 & \multicolumn{2}{|c|}{ Durbin-Watson stat } & 1.827272 \\
\hline Prob(F-statistic) & 0.999657 & & & \\
\hline
\end{tabular}

Source: Eviews.

Based on the estimation results which show in table 6 , the VIF value $>10$ indicates that there is multicolonierity (the relationship between independent variables).

Tabel 6 - Variance Inflation Factor (VIF)Test

\begin{tabular}{|c|c|c|c|}
\hline \multicolumn{4}{|c|}{ Variance Inflation Factors } \\
\hline \multicolumn{4}{|c|}{ Date: $11 / 02 / 20$ Time: $20: 38$} \\
\hline \multicolumn{4}{|c|}{ Sample: 2011Q1 2019Q4 } \\
\hline \multicolumn{4}{|c|}{ Included observations: 35} \\
\hline Variable & Coefficient Variance & Uncentered VIF & Centered VIF \\
\hline C & 0.000232 & 93.38997 & NA \\
\hline LNFAGR & 0.001445 & 390.6314 & 53.77065 \\
\hline LNFMN & 0.001007 & 162.6825 & 23.96093 \\
\hline LNFIND & 0.001943 & 911.6837 & 87.34038 \\
\hline LNFEGW & 0.000638 & 164.7571 & 19.39411 \\
\hline LNFCONC & 0.000885 & 412.5581 & 19.69774 \\
\hline
\end{tabular}

Source: Eviews.

To ensure perfect multicollinearity between independent variables, according to Fisher, it is necessary to test with Auxiliary Regression. Auxiliary regression is done by comparing the determistic coefficients (R2). According to the klein of thumb, if the coefficient determination of the auxiliary regression is greater than the coefficient of the original regression model, it is subject to multicollinearity. Table 7 shows the result of Model Auxilary Test. 
Eurasia: Economics \& Business, 2(44), February 2021

DOI https://doi.org/10.18551/econeurasia.2021-02

Table 7 - Model Auxilary Test

\begin{tabular}{llll}
\hline Model & $\begin{array}{l}\text { The deterministic coefficient (R2) } \\
\text { of model auxiliary }\end{array}$ & The determistic coefficient (R2) model & Multicolonierity Conclusion \\
\hline Infagr c Infmn Infind Infegw Infconc & 0,98 & 0,98 & No \\
Infmn c Infagr Infind Infegw Infconc & 0,96 & 0,98 & No \\
Infind c Infagr Infmn Infegw Infconc & 0,98 & 0,98 & No \\
Infegw c Infind Infagr Infmn Infconc & 0,95 & 0,98 & No \\
Infconc c Infegw Infind Infagr Infmn & 0,95 & 0,98 & No \\
\hline
\end{tabular}

Source: Eviews.

Based on the table 7, it can be concluded that all variables do not experience multicollinearity.

Based on the results of the estimation of the effect of sectoral financing on Islamic banking to economic growth, it can be presented in the following table:

Table 8 - Ordinary Least Square (OLS)

Dependent Variable: LNGDP

Method: Least Squares

Date: 11/02/20 Time: 20:46

Sample (adjusted): 2011Q1 2019Q3

Included observations: 35 after adjustments

\begin{tabular}{|c|c|c|c|c|}
\hline Variable & Coefficient & Std. Error & t-Statistic & Prob. \\
\hline $\begin{array}{l}\text { C } \\
\text { LNFAGR } \\
\text { LNFMN } \\
\text { LNFIND } \\
\text { LNFEGW } \\
\text { LNFCONC }\end{array}$ & $\begin{array}{l}3.176093 \\
0.095457 \\
0.017332 \\
-0.046940 \\
0.078799 \\
0.074400\end{array}$ & $\begin{array}{l}0.015222 \\
0.038010 \\
0.031736 \\
0.044078 \\
0.025263 \\
0.029742\end{array}$ & $\begin{array}{l}208.6545 \\
2.511359 \\
0.546146 \\
-1.064931 \\
3.119122 \\
2.501560\end{array}$ & $\begin{array}{l}0.0000 \\
0.0179 \\
0.5891 \\
0.2957 \\
0.0041 \\
0.0183\end{array}$ \\
\hline $\begin{array}{l}\text { R-squared } \\
\text { Adjusted R-squared } \\
\text { S.E. of regression } \\
\text { Sum squared resid } \\
\text { Log likelihood } \\
\text { F-statistic } \\
\text { Prob(F-statistic) }\end{array}$ & $\begin{array}{l}0.977346 \\
0.973440 \\
0.009319 \\
0.002518 \\
117.2792 \\
250.2234 \\
0.000000\end{array}$ & \multicolumn{2}{|c|}{$\begin{array}{l}\text { Mean dependent var } \\
\text { S.D. dependent var } \\
\text { Akaike info criterion } \\
\text { Schwarz criterion } \\
\text { Hannan-Quinn criter. } \\
\text { Durbin-Watson stat }\end{array}$} & $\begin{array}{l}3.348000 \\
0.057179 \\
-6.358810 \\
-6.092178 \\
-6.266768 \\
1.747020\end{array}$ \\
\hline
\end{tabular}

Source: Eviews.

Based on the table 8 , the equation model is obtained as follows:

LNGDP $=3.176+0.0954^{*}$ LNFAGR $+0.0173^{*}$ LNFMN $-0.0469^{*}$ LNFIND $+0.0788^{*}$ LNFEGW $+0.0744^{*}$ LNFCONC

The R-Square value of 98 percent is influenced by the financing variable in the agricultural sector, the mining sector, the industrial sector, the electricity sector, gas and water and the construction sector, while the remaining 2 percent is influenced by other variables outside the model.

The agricultural sector is a very important sector in the Indonesian economy. This sector concerns the fisheries and forestry sectors. The agricultural sector is a supplier for the population's food needs, a supplier of raw materials for industry, a source of state income and a sector that absorbs the highest number of workers. Based on BPS data as of February 2019, the number of workers absorbed in this sector is 29.46 percent. Although the contribution of this sector to GDP shows a decrease, the agricultural sector still contributes 12.90 percent in 2019 , the third position after trade and the industrial sector. Financing in the agricultural sector is not too prominent when compared to the industrial and construction sectors. This is probably because farmers are members of rural cooperatives so that financing is managed by direct cooperatives. In addition, farmers do not have sufficient collateral to finance banks so that the expansion of financing in this sector is still small. 
However, based on the results of data processing, it is known that Islamic banking financing in the agricultural sector has a positive effect on economic growth with a coefficient value of 0.095457 , which means that every 1 percent growth in Islamic bank financing in the agricultural sector will increase GDP growth by 0.095457 percent.

The positive effect of financing in Islamic banking on economic growth was also stated by Asngari (2015) which stated that the higher the financing channeled by Islamic banking, the higher the economic growth. But There are different outcomes for the agricultural sector which has estimate by Indrawan \& Rahman (2020), they found that economic growth is significantly but negatively affected by Islamic banking Finance in both the short and long term.

The mining sector's GDP contribution to economic growth in the last five years has decreased from 8.82 percent in 2015 to 7.68 percent in 2019. The mining sector only absorbs 1.06 percent of the total workforce according to employment. Islamic banking financing in this sector is the least when compared to financing from the other four sectors. Mining sector financing has a high risk due to the weak price of metal commodities such as tin, nickel, aluminum and coal (www.finansialbisnis.com, retrieved December 8, 2020).

Based on the regression results, the relationship between mining sector financing on economic growth is not significant where the probability value is greater than $\alpha=0.05$. The mining sector coefficient value of 0.0173 percent does not have a significant effect on economic growth. The results of this estimate are the same as previous research conducted by (Susilo \& Ratnawati, 2013) who said that only the mining and excavation sector has an insignificant relationship to economic growth.

Based on the OLS estimation results, it is found that the coefficient value of industrial sector financing is -0.046940 and the probability is $0.2957>\alpha=0.05$ which illustrates that the financing of the industrial sector in Islamic banking does not have a significant effect on economic growth. An increase in industrial sector financing by 1 percent is able to reduce GDP by 0.46940 percent. This is inversely proportional to the theory explained by Schumpeter who argues that economic growth is largely determined by entrepreneurial ability (entrepreneurship) because entrepreneurs are able to innovate in production activities. The existence of a stock of new relevant ideas and the existence of sources of capital from financial institutions can create innovations that can drive economic growth.

The absence of influences between Islamic banking financing on economic growth was also revealed by Afandi \& Amin (2019) they revealed that investment financing has a negative effect on economic growth. This is in line with the results of this paper where the industrial sector uses more investment financing products in developing its business so that the industrial sector in this study has a negative effect on economic growth.

The same result was also revealed by Indrawan \& Rahman (2020), Islamic Banking Financing in industrial sector was found to be significant in the short term in a positive direction, but no long-term relationship was found because there was no cointegration.

The Islamic financing in electricity, gas and water sector experienced a significant growth from 8 trillion in 2017 to 14 trillion in 2019. This sector is only able to absorb labor around 0.24 percent from the the total population working according to business fields.

Based on the regression results, it is known that the coefficient value of Islamic banking financing in the electricity, gas and water sector is 0.078 percent and the probability is 0.0041 or less than $\alpha=0.05$. This means that every time there is an increase in the financing of the electricity, gas and water sectors in Islamic banking by 1 percent, it will significantly affect economic growth by 0.078 percent.

Construction sector financing experienced a significant growth. In 2011, the amount of lending in this sector only reached 4,594 million and increased in the fourth quarter of 2019 to 30,053 million. So that this sector provides the largest amount of financing compared to the other four sectors in the research.

Despite being the first position in lending, this is not in line with its contribution to national GDP. The construction sector occupies the fourth position in its contribution to GDP. One of the reasons is due to the inadequate absorption of labor. Based on BPS data as of 
February 2019, this sector is only able to absorb labor of 5.89 percent from total population working according to business fields.

The coefficient value of construction sector financing in Islamic banking is 0.0744 percent and the probability is 0.0183 or less than $\alpha=0.05$, which means that every 1 percent increase in Islamic banking financing in the construction sector will significantly affect 0.0744 percent of economic growth.

\section{CONCLUSION}

The estimation result using the least square method shows that the R-Square value of 98 percent is influenced by the variable of financing in the agricultural sector, mining sector, industrial sector, electricity sector, gas and water and the construction sector, while the remaining 2 percent is influenced by other variables outside the model. The agriculture, mining, electricity, gas \& water and construction sectors have a positive influence on economic growth. Meanwhile, the industrial sector has a negative influence on economic growth. The results of this study are expected to be useful for making policies so that they can prioritize financing for sectors that have a major contribution to economic growth and can determine the direction of policies in Indonesia's economic development.

\section{REFERENCES}

1. Abduh, M. dan C. (2012). Does Islamic Banking Matter For Economic Growth In Bangladesh? Journal of Islamic Economic, Banking and Finance, 8(3).

2. Afandi, M. A., \& Amin, M. (2019). Islamic Bank Financing and Its Effects on Economic Growth: A Cross Province Analysis. Signifikan: Jurnal Ilmu Ekonomi, 8(2), 243-250. https://doi.org/10.15408/sjie.v8i2.10977.

3. Ananzeh, I. E. N. (2016). Relationship between Bank Credit and Economic Growth: Evidence from Jordan. International Journal of Financial Research, 7(2). https://doi.org/10.5430/ijfr.v7n2p53.

4. Asngari, I. (2015). Pengaruh Pembiayaan Bank Syariah Terhadap Pertumbuhan Ekonomi Indonesia. Seminar Nasional, 54, 23-24.

5. Baehaqy, H. N., \& Cahyono, E. F. (2020). Pengaruh Pembiayaan Perbankan Konvensional dan Pembiayaan Perbankan Syariah terhadap Pertumbuhan Ekonomi di Indonesia pada Tahun 2008-2018. Jurnal Ekonomi Syariah Teori Dan Terapan, 6(6), 1271-1286.

6. Boukhatem, J., \& Ben Moussa, F. (2018). The effect of Islamic banks on GDP growth: Some evidence from selected MENA countries. Borsa Istanbul Review, 18(3), 231-247. https://doi.org/10.1016/j.bir.2017.11.004.

7. Domar, H. (1957). Model Pertumbuhan Ekonomi. Jakarta: PT. Raja Grafindo Pustaka.

8. El Ayyubi, S., Anggraeni, L., \& Mahiswari, A. D. (2018). Pengaruh Bank Syariah terhadap Pertumbuhan Ekonomi di Indonesia. Al-Muzara'ah, 5(2), 88-106. https://doi.org/10.29244/jam.5.2.88-106.

9. Gaffar, E., \& Osman, A. (2014). The Impact of Private Sector Credit on Saudi Arabia Economic Growth (GDP): An Econometrics Model Using (ARDL) Approach to Cointegration. American International Journal of Social Science, 3(6), 109-117.

10. Indrawan, I. W., \& Rahman, M. P. (2020). Sectoral Analysis on the Impact of Islamic Banks To the Malaysian Economy. Journal of Islamic Monetary Economics and Finance, 6(1), 163-188. https://doi.org/10.21098/jimf.v6i1.1119.

11. Mankiw, G. (2006). Makro Ekonomi. Jakarta: Erlangga.

12. Oni, I. O., Akinlo, A. E., \& Oladepo, E. D. (2014). Impact of Bank Credit on the Real Sector: Evidence From Nigeria. Global Journal of Business Research (GJBR), 8(3), 3947. Retrieved from http://search.ebscohost.com

13. Orji, A., Ogbuabor, J. E., \& Anthony-Orji, O. I. (2015). Financial liberalization and economic growth in Nigeria: An empirical evidence. International Journal of Economics and Financial Issues, 5(3), 663-672. 
14. Setiawan, I. (2019). The Role of Islamic Banking in the Development of Economic Sectors in Indonesia. International Journal of Applied Business Research, 1(02), 88-99. https://doi.org/10.35313/ijabr.v1i02.70.

15. Sipahutar, M. A. (2016). Effects of Credit on Economic Growth, Unemployment and Poverty. Jurnal Ekonomi Pembangunan: Kajian Masalah Ekonomi Dan Pembangunan, 17(1), 37. https://doi.org/10.23917/jep.v17i1.1651.

16. Standard, D. (2019). State of the Global Islamic Economy Report 2019/20. Dubai International Financial Centre, 1-174. Retrieved from https://haladinar.io/hdn/doc/report2018.pdf.

17. Suna, K. (2015). Impact of Bank Credits on Economic Growth and Inflation. Journal of Applied Finance \& Banking, 5(1), 57-69. Retrieved from http://www.scienpress.com/Upload/JAFB/Vol 5_1_4.pdf.

18. Susilo, J., \& Ratnawati, N. (2013). Analisis pengaruh pembiayaan bank syariah dan tenaga kerja terhadap peningkatan produk domestik bruto (pdb) analisis sektoral tahun 2006-2013. The Russian Union Catalog of Scientific Literature (Russian), 6(3), 1-6. Retrieved from http://library.gpntb.ru/cgibin/irbis64r/62/cgiirbis_64.exe?C21COM=S\&I21DBN=RSK\&P21DBN=RSK\&S21FMT=full webr\&Z21ID $=\& S 21 \mathrm{STN}=1 \& S 21 \mathrm{REF}=10 \& \mathrm{Z} 21 \mathrm{MFN}=856891$.

19. Terminanto, A. A., \& Rama, A. (2017). Pembiayaan Bank Syariah Terhadap Pertumbuhan Ekonomi : Studi Kasus. Iqtishadia, 10(1).

20. Yusof, R. M., \& Bahlous, M. (2013). Islamic banking and economic growth in GCC \& East Asia countries: A panel cointegration analysis. Journal of Islamic Accounting and Business Research, 4(2), 151-172. https://doi.org/10.1108/JIABR-07-2012-0044. 